\title{
Ferrite grade iron oxides from ore rejects
}

\author{
K S RANE*, V M S VERENKAR and P Y SAWANT \\ Department of Chemistry, Goa University, Goa 403 206, India
}

MS received 13 October 2000; revised 5 March 2001

\begin{abstract}
Iron oxyhydroxides and hydroxides were synthesized from chemically beneficiated high $\mathrm{SiO}_{2} / \mathrm{Al}_{2} \mathrm{O}_{3}$ low-grade iron ore $\left(57.49 \% \mathrm{Fe}_{2} \mathrm{O}_{3}\right)$ rejects and heated to get iron oxides of 96-99.73\% purity. The infrared band positions, isothermal weight loss and thermogravimetric and chemical analysis established the chemical formulas of iron-oxyhydroxides as $\gamma$-FeOOH.0.3 $\mathrm{H}_{2} \mathrm{O} ; \alpha$-FeOOH.0.2 $\mathrm{H}_{2} \mathrm{O}$ and amorphous $\mathrm{FeOOH}$. The thermal products of all these were $\alpha-\mathrm{Fe}_{2} \mathrm{O}_{3}$ excepting that of $\gamma$-FeOOH.0.3H $3 \mathrm{O}$ which gave mainly $\gamma-\mathrm{Fe}_{2} \mathrm{O}_{3}$ and some admixture of $\alpha-\mathrm{Fe}_{2} \mathrm{O}_{3}$. The hydrazinated iron hydroxides and oxyhydroxides, on the other hand, decomposed autocatalytically to mainly $\gamma-\mathrm{Fe}_{2} \mathrm{O}_{3}$. Hydrazine method modifies the thermal decomposition path of the hydroxides. The saturation magnetization, $J_{\mathrm{s}}$, values were found to be in the range $60-71 \mathrm{emu} \mathrm{g}^{-1}$ which are close to the reported values for $\gamma-\mathrm{Fe}_{2} \mathrm{O}_{3}$. Mechanism of the $\gamma-\mathrm{Fe}_{2} \mathrm{O}_{3}$ formation by hydrazine method is discussed.
\end{abstract}

Keywords. Ore rejects; chemical beneficiation; iron hydroxide; iron oxyhydroxide; ferrite.

\section{Introduction}

The ferrites, both hard and soft, find technological importance in ever expanding electronic industry and this is evident from the estimated world ferrite production (Ruthner 1989,1997 ) of $5,16,000$ metric tons per year (MTPY) in 1990 and 15,00,000 MTPY in the year 2005. The ferrite grade iron oxide, $\alpha-\mathrm{Fe}_{2} \mathrm{O}_{3}$, required for such a production of ferrites in year 2005 would be of about 10,50,000 MTPY. The ferrites production had been on rise ever since the commercialization of these took place some 60 years ago (Sugimoto 1999) and comparing with the world ferrite producing countries capacity (Ruthner 1989) the Indian contribution was mere $2 \%$ in 70 s and 80 s. And there is no significant improvement in the Indian ferrite production capacity, at present. India can certainly increase its ferrite production capacity, as we have huge iron oxide sources in our country. It is being estimated (Ruthner 1989) that the iron oxide required for such a huge production of ferrites would mostly come from the upgraded hematite ore and we have plenty of that sort of iron oxide sources. But, the Indian iron mine industry caters high-grade ore for the domestic steel industry requirements and export, and the highly mechanized industry discards the low-grade ore and tailings at the mining areas that are creating environmental problems. And, considering deteriorating mineral resources, it is high time that one should look into the low-grade ores to make them value added materials. We (Verenkar 1997; Sawant 1998; Rane et al 1999, 2000) have been making a modest effort to make use of these ore rejects to synthe-

*Author for correspondence size active pure iron oxides and from these ferrites to see the suitability of such iron oxide sources in ferrite industry, after chemical beneficiation.

Advantages of chemically synthesized iron oxides are many as one can get (i) impurity free fine particles of high surface area and hence reactive and (ii) oxide of desired crystal structure. The need of high surface area fine particles in solid state reactions is well known and industrial process for achieving this is mechanical grinding. The necessity of desired crystal structure of the raw materials seems also essential in obtaining ferrite of good quality. We (Verenkar 1997; Sawant 1998; Rane et al 1999, 2000) observed the formation of low porosity single phase $\mathrm{MgFe}_{2} \mathrm{O}_{4}$ of uniform saturation magnetization, $4 \pi M_{\mathrm{s}} \cong$ 1000-1150 Gauss, from synthetic cubic iron oxide, $\gamma$ $\mathrm{Fe}_{2} \mathrm{O}_{3}$ and cubic $\mathrm{MgO}$ at $1000^{\circ} \mathrm{C}$. On the other hand, a high porosity and low $4 \pi M_{\mathrm{s}}(609 \mathrm{G})$ mixed phase $\mathrm{MgFe}_{2} \mathrm{O}_{4}$ containing unreacted $\alpha-\mathrm{Fe}_{2} \mathrm{O}_{3}$ was obtained at $1000^{\circ} \mathrm{C}$ from the usual ferrite raw material of commercial grade hexagonal, corundum $\alpha-\mathrm{Fe}_{2} \mathrm{O}_{3}$.

The high reactivity of the synthetic $\gamma-\mathrm{Fe}_{2} \mathrm{O}_{3}$ is no doubt due to their fine particles of nanometer size. But, the cubic structure of $\gamma-\mathrm{Fe}_{2} \mathrm{O}_{3}$ may also be the reason for it to easily react with cubic $\mathrm{MgO}$ to give cubic spinel $\mathrm{MgFe}_{2} \mathrm{O}_{4}$, while the hexagonal corundum $\alpha-\mathrm{Fe}_{2} \mathrm{O}_{3}$ may not react that easily. Solid state reactions are sluggish and several factors influence the reactivity such as particle size, gas atmosphere, and defect nature of the reactants. As compared to the hexagonal corundum $\alpha-\mathrm{Fe}_{2} \mathrm{O}_{3}$, the cubic $\gamma$ $\mathrm{Fe}_{2} \mathrm{O}_{3}$ is a defect spinel with vacancies on the octahedral sites. The unit cell structure of $\gamma-\mathrm{Fe}_{2} \mathrm{O}_{3}$ is represented as, $\left(\mathrm{Fe}_{8}^{3+}\right)_{\text {tetr. }}\left[\mathrm{Fe}_{40 / 3}^{3+} \square_{8 / 3}\right]_{\text {oct }} \mathrm{O}_{32}$ and this defective iron oxide may have superior reactivity. The enhanced reactivity of $\gamma-\mathrm{Fe}_{2} \mathrm{O}_{3}$ may also be viewed as due to its phase transfor- 
mation to $\alpha-\mathrm{Fe}_{2} \mathrm{O}_{3}$ during the heat treatment in ferrite preparation. The $\gamma$ - to $\alpha$-phase transformation takes place at $\sim 350^{\circ} \mathrm{C}$. Certain solid state reactions are favoured (Rao and Gopalakrishnan 1997) if they are carried out at the phase transformation of one of the reactants (Hedvall effect); formation of $\mathrm{CoAl}_{2} \mathrm{O}_{4}$ is easier at the $\gamma \rightarrow \alpha$ transition of $\mathrm{Al}_{2} \mathrm{O}_{3}$.

The use of $\gamma-\mathrm{Fe}_{2} \mathrm{O}_{3}$ in the synthesis of ferrites giving superior magnetic properties in systems such as $\mathrm{ZnFe}_{2} \mathrm{O}_{4}$ (Huhn 1987), NiZn ferrites (Shrotri et al 1992), LiMn ferrite (Sano and Tamaura 1999) are in conformity with our own studies on $\mathrm{MgFe}_{2} \mathrm{O}_{4}$ (Verenkar 1997; Sawant 1998; Rane et al 1999, 2000). Having understood the effectiveness of $\gamma-\mathrm{Fe}_{2} \mathrm{O}_{3}$ in ferrites synthesis we investigated different techniques to prepare the oxide easily, as the commercial manufacture of the oxide is a multi step process,

$$
\begin{gathered}
\alpha-\mathrm{FeOOH} \stackrel{\text { oxidation }}{\longrightarrow} \alpha-\mathrm{Fe}_{2} \mathrm{O}_{3} \stackrel{\text { reduction }}{\longrightarrow} \mathrm{Fe}_{3} \mathrm{O}_{4} \\
\stackrel{\text { controlled [O] }}{\longrightarrow} \gamma-\mathrm{Fe}_{2} \mathrm{O}_{3} .
\end{gathered}
$$

There are several methods of preparation of active iron oxide, $\alpha-\mathrm{Fe}_{2} \mathrm{O}_{3}$, from precursors such as hydroxides, oxyhydroxides, carboxylates, etc. $\gamma$-FeOOH on dehydration yields, $\gamma-\mathrm{Fe}_{2} \mathrm{O}_{3}$, but the commercial $\gamma-\mathrm{Fe}_{2} \mathrm{O}_{3}$ is a magnetic recording material of needle shape which is being synthesized from acicular $\alpha-\mathrm{FeOOH}$, as shown in (1). Since our requirement of $\gamma-\mathrm{Fe}_{2} \mathrm{O}_{3}$ in ferrite synthesis is not of acicular one, any method which gives the oxide in fine size is good enough.

\subsection{Hydrazine method}

We adopted (Rane et al 1981) the decomposition of ferrous oxalate dihydrate precursor in a controlled moisture atmosphere to get $\gamma-\mathrm{Fe}_{2} \mathrm{O}_{3}$ at $\sim 310^{\circ} \mathrm{C}$. However, we found (Moye et al 1993) that the hydrazine complex of the ferrous oxalate decomposed autocatalytically at an ordinary temperature and pressure when a small portion was ignited with a burning splinter. The decomposition occurred instantaneously yielding mainly $\gamma-\mathrm{Fe}_{2} \mathrm{O}_{3}$. Several ferrous carboxylato-hydrazinates were also found (Verenkar 1997; Rane et al 2001) to decompose autocatalytically to $\gamma-\mathrm{Fe}_{2} \mathrm{O}_{3}$. Although $\gamma$-FeOOH dehydrates at $\sim 300^{\circ} \mathrm{C}$ to $\gamma-\mathrm{Fe}_{2} \mathrm{O}_{3}$, the hydrazinated iron oxyhydroxide immediately catches fire when exposed to air yielding $\gamma-\mathrm{Fe}_{2} \mathrm{O}_{3}$ of superior magnetic characteristics (Verenkar 1997) compared to the product of the un-hydrazinated $\gamma$-FeOOH.

Hydrazine method of preparation of transition to rare earth metal oxides of spinel and perovskite structure is a novel way adopted (Ferrari et al 1966; Braibanti et al 1969; Sharov et al 1977; Patil and Pai Verenkar 1982; Ravindranathan and Patil 1987; Kikkawa et al 1995; Patil et al 1997) to obtain fine nano metre sized reactive substances. We prepared active $\gamma-\mathrm{Fe}_{2} \mathrm{O}_{3}, \mathrm{NiZn} / \mathrm{MnZn} / \mathrm{Mg}$ ferrites (Moye et al 1990, 1993; Verenkar 1997; Sawant 1998; Rane et al 1999, 2000) by hydrazine method. The $\mathrm{MgFe}_{2} \mathrm{O}_{4}$ synthesized from synthetic iron oxides (mainly $\gamma-\mathrm{Fe}_{2} \mathrm{O}_{3}$ ) from iron ore rejects by the hydrazine method indicated superior magnetic and electrical properties as compared to the ferrite prepared from commercial grade $\alpha-\mathrm{Fe}_{2} \mathrm{O}_{3}$. Here in this paper we discuss the novel hydrazine method of easy preparation of $\gamma-\mathrm{Fe}_{2} \mathrm{O}_{3}$ from iron hydroxide and iron oxyhydroxides obtained from iron ore rejects.

\section{Experimental}

High $\mathrm{SiO}_{2} / \mathrm{Al}_{2} \mathrm{O}_{3}=2.56$ low grade iron ore $(57.49 \%$ $\mathrm{Fe}_{2} \mathrm{O}_{3}$ ) rejects were extracted with acid and precipitated as iron hydroxide and iron oxyhydroxides: $\gamma$-FeOOH, $\alpha-$ $\mathrm{FeOOH}$ and amorphous $\mathrm{FeOOH}$ using precipitants (Verenkar 1997; Sawant 1998) such as $\mathrm{NH}_{3}, \mathrm{NaOH}, \mathrm{NaOH}+$ $\mathrm{NH}_{3}$, and $\mathrm{Na}_{2} \mathrm{CO}_{3}$. The thermal products at $\sim 300^{\circ} \mathrm{C}$ of all these hydroxides yielded $96-98 \%$ pure iron oxide, $\alpha$ $\mathrm{Fe}_{2} \mathrm{O}_{3}$, excepting $\gamma$-FeOOH which transformed into mainly $\gamma-\mathrm{Fe}_{2} \mathrm{O}_{3}$ and partly $\alpha-\mathrm{Fe}_{2} \mathrm{O}_{3}$. Also a solvent extraction method using methyl iso-butyl ketone (MIBK) was adopted to get $99.73 \%$ pure iron oxide. The chemical beneficiation reduced the $\mathrm{SiO}_{2} / \mathrm{Al}_{2} \mathrm{O}_{3}$ ratio to $0 \cdot 02$.

\subsection{Hydrazine method}

The iron hydroxide and oxyhydroxides were then equilibrated with hydrazine by storing them on a petri dish over hydrazine hydrate, $\mathrm{N}_{2} \mathrm{H}_{4} \cdot \mathrm{H}_{2} \mathrm{O}(99 \%)$, in a desiccator for 4-5 days. On exposure to ordinary atmosphere they all autocatalytically decomposed to iron oxides, mainly $\gamma$ $\mathrm{Fe}_{2} \mathrm{O}_{3}$.

\subsection{Analysis}

Chemical analysis of iron was done by standard method. Pyknometric density measurements were done in $\mathrm{CCl}_{4}$. Infrared band positions were detected on Schimadzu FTIR instrument, model 8101A. Isothermal weight loss of the hydroxides and iron oxyhydroxides was established in a muffle furnace. Thermogravimetric analysis was done on Rigaku TAS 1000 instrument in $\mathrm{N}_{2}$ atmosphere. The Xray diffraction patterns of all oxide products were obtained on Rigaku DMAX II using $\mathrm{Cu}$ and Fe targets. Saturation magnetization values, $J_{\mathrm{s}}$ in emu g $\mathrm{g}^{-1}$, of all oxide products were measured using an alternating current high field hysteresis loop tracer (Likhite et al 1965) supplied by M/s Arun Electronics, Mumbai, India. Pure nickel $(99.9 \%)$ was used as a standard. Scanning electron microscopic (SEM) studies done on Cambridge Stereoscan 
S 250 MK III were used to find out the particle size distributions in the final oxide products.

\section{Results and discussion}

\subsection{Phase identification}

The $d_{h k l}$ values of all oxide products were compared with the JCPDS files: 24-81 and 25-1402. All were found to be mainly $\gamma-\mathrm{Fe}_{2} \mathrm{O}_{3}$ as shown in table 1 . The X-ray diffraction (XRD) pattern of one representative sample of $\gamma$ $\mathrm{Fe}_{2} \mathrm{O}_{3}$ obtained from autocatalytically decomposed hydrazinated $\gamma-\mathrm{FeOOH}$ and one standard commercial $\gamma-\mathrm{Fe}_{2} \mathrm{O}_{3}$ is shown in figure 1 . The detailed $d_{h k l}$ values of all other samples are tabulated in table 1. A thermal dehydration of the unhydrazinated $\gamma$-FeOOH gives $\gamma-\mathrm{Fe}_{2} \mathrm{O}_{3}$ the XRD pattern of which, however, is similar to figure 1 , but with few extra peaks (table 1) attributing to the presence of $\alpha-\mathrm{Fe}_{2} \mathrm{O}_{3}$ along with the main product $\gamma-\mathrm{Fe}_{2} \mathrm{O}_{3}$. $\alpha$ $\mathrm{FeOOH}$ dehydrates in air to give $\alpha-\mathrm{Fe}_{2} \mathrm{O}_{3}$, while the hydrazinated iron oxyhydroxide decomposes to form a mixture of $\gamma-\mathrm{Fe}_{2} \mathrm{O}_{3}$ and $\alpha-\mathrm{Fe}_{2} \mathrm{O}_{3}$.

The hydrazinated amorphous $\mathrm{FeOOH}$ autocatalytically decomposes to $\gamma-\mathrm{Fe}_{2} \mathrm{O}_{3}$, while the unhydrazinated one dehydrates into $\alpha-\mathrm{Fe}_{2} \mathrm{O}_{3}$. Thus the hydrazination method yields easily $\gamma-\mathrm{Fe}_{2} \mathrm{O}_{3}$ from iron oxyhydroxides.

\subsection{Magnetic characterization}

The saturation magnetization values, $J_{\mathrm{s}}$, for all these oxide products were obtained from the high field hysteresis loops using $\mathrm{Ni}$ as a standard and a representative loop of
$\gamma-\mathrm{Fe}_{2} \mathrm{O}_{3}$ prepared from the autocatalytic decomposition of hydrazinated $\gamma-\mathrm{FeOOH}$ is shown in figure 2. The figure also shows the detailed $J_{\mathrm{s}}$ values in emu g${ }^{-1}$ of all the oxide products that fell in the range $2 \cdot 36-71.65 \mathrm{emu}^{-1}$. The saturation magnetization, $J_{\mathrm{s}}$ of $71.65 \mathrm{emu} \mathrm{g}^{-1}$ was observed for $\gamma-\mathrm{Fe}_{2} \mathrm{O}_{3}$ prepared from the autocatalytically decomposed hydrazinated $\gamma$ - $\mathrm{FeOOH}$ and the value is close to the reported (Khalafalla and Morrish 1972) value of 71-74 emu g ${ }^{-1}$. The mixture of $\gamma-\mathrm{Fe}_{2} \mathrm{O}_{3}$ and $\alpha-\mathrm{Fe}_{2} \mathrm{O}_{3}$ obtained by heating $\gamma$-FeOOH in air amounts to lower $J_{\mathrm{s}}$ value of $19.20 \mathrm{emu} \mathrm{g}^{-1}$ and this suggests that the hydrazine method produces single phase $\gamma-\mathrm{Fe}_{2} \mathrm{O}_{3}$ of better magnetic character.

$\alpha-\mathrm{FeOOH}$ in air decomposed to a non magnetic $\alpha$ $\mathrm{Fe}_{2} \mathrm{O}_{3}$ and it showed $J_{\mathrm{s}}$ value of $2.36 \mathrm{emu} \mathrm{g}^{-1}$, while the mixed products $\gamma-\mathrm{Fe}_{2} \mathrm{O}_{3}+\alpha-\mathrm{Fe}_{2} \mathrm{O}_{3}$ obtained from autocatalytically decomposed hydrazinated $\alpha$-FeOOH showed an increased $J_{\mathrm{s}}$ of $16.03 \mathrm{emu} \mathrm{g}^{-1}$, suggesting that the hydrazine method modifies the decomposition path of the oxyhydroxide. The thermal product of amorphous $\mathrm{FeOOH}$ showed a low $J_{\mathrm{s}}$ of $2.46 \mathrm{emu} \mathrm{g}^{-1}$ which means the formed oxide product was $\alpha-\mathrm{Fe}_{2} \mathrm{O}_{3}$, but the hydrazine method yielded a product, $\gamma-\mathrm{Fe}_{2} \mathrm{O}_{3}$ of high $J_{\mathrm{s}}$ of $60 \cdot 14 \mathrm{emu} \mathrm{g}^{-1}$. These results are in conformity with the X-ray phase analysis (table 1). The $J_{\mathrm{s}}$ values in the range of 50 $74 \mathrm{emu} \mathrm{g}^{-1}$ were also observed (Coey and Khalafalla 1972; Khalafalla and Morrish 1972) for $\gamma-\mathrm{Fe}_{2} \mathrm{O}_{3}$ synthesized from different techniques and hence our values in the range $60-71$ emu $^{-1}$ for the oxide from $\gamma$-FeOOH and amorphous $\mathrm{FeOOH}$ by hydrazine method suggest that the hydrazination modifies the thermal decomposition path of these oxyhydroxides.

Table 1. X-ray data of iron oxides obtained by autocatalytic decomposition of hydrazinated iron oxyhydroxides and $\gamma$-FeOOH in air.

\begin{tabular}{|c|c|c|c|c|c|c|c|c|c|c|c|c|}
\hline $\begin{array}{l}\gamma-\mathrm{Fe}_{2} \mathrm{O}_{3} * \\
\text { Tetragonal }\end{array}$ & $\begin{array}{l}D \\
I / I_{0}\end{array}$ & - & $\begin{array}{l}2 \cdot 95 \\
30\end{array}$ & $\begin{array}{l}2 \cdot 78 \\
13\end{array}$ & $\begin{array}{l}- \\
-\end{array}$ & $\begin{array}{l}2 \cdot 51 \\
100\end{array}$ & $\begin{array}{l}2 \cdot 09 \\
15\end{array}$ & - & $\begin{array}{l}1 \cdot 70 \\
19\end{array}$ & $\begin{array}{l}1 \cdot 60 \\
20\end{array}$ & $\begin{array}{l}1.47 \\
40\end{array}$ & $\begin{array}{l}1 \cdot 27 \\
08\end{array}$ \\
\hline $\begin{array}{c}\gamma-\mathrm{Fe}_{2} \mathrm{O}_{3} * \\
\text { Cubic }\end{array}$ & $\begin{array}{l}D \\
I / I_{0}\end{array}$ & - & $\begin{array}{l}2 \cdot 95 \\
30\end{array}$ & $\begin{array}{l}2 \cdot 78 \\
19\end{array}$ & $\begin{array}{l}- \\
-\end{array}$ & $\begin{array}{l}2 \cdot 52 \\
100\end{array}$ & $\begin{array}{l}2 \cdot 08 \\
24\end{array}$ & - & $\begin{array}{l}1 \cdot 70 \\
12\end{array}$ & $\begin{array}{l}1 \cdot 61 \\
33\end{array}$ & $\begin{array}{l}1.48 \\
53\end{array}$ & $\begin{array}{l}1 \cdot 27 \\
11\end{array}$ \\
\hline $\mathrm{Fe}_{3} \mathrm{O}_{4} *$ & $\begin{array}{l}D \\
I / I_{0}\end{array}$ & $\begin{array}{l}- \\
-\end{array}$ & $\begin{array}{l}2 \cdot 97 \\
30\end{array}$ & $\begin{array}{l}- \\
-\end{array}$ & $\begin{array}{l}- \\
-\end{array}$ & $\begin{array}{l}2 \cdot 53 \\
100\end{array}$ & $\begin{array}{l}2 \cdot 09 \\
20\end{array}$ & - & $\begin{array}{l}1 \cdot 71 \\
10\end{array}$ & $\begin{array}{l}1 \cdot 61 \\
30\end{array}$ & $\begin{array}{l}1.48 \\
40\end{array}$ & $\begin{array}{l}1 \cdot 28 \\
10\end{array}$ \\
\hline$\alpha-\mathrm{Fe}_{2} \mathrm{O}_{3} *$ & $\begin{array}{l}D \\
I / I_{0}\end{array}$ & $\begin{array}{l}3 \cdot 66 \\
25\end{array}$ & $\begin{array}{l}- \\
-\end{array}$ & - & $\begin{array}{l}2 \cdot 69 \\
100\end{array}$ & $\begin{array}{l}2 \cdot 51 \\
50\end{array}$ & $\begin{array}{l}2 \cdot 20 \\
30\end{array}$ & $\begin{array}{l}1 \cdot 84 \\
40\end{array}$ & $\begin{array}{l}1 \cdot 69 \\
60\end{array}$ & $\begin{array}{l}- \\
-\end{array}$ & $\begin{array}{l}1 \cdot 45 \\
35\end{array}$ & $\begin{array}{l}- \\
-\end{array}$ \\
\hline $\begin{array}{l}\gamma \text {-FeOOH (in air) } \\
\text { Decomp. }\end{array}$ & $\begin{array}{l}D \\
I / I_{0}\end{array}$ & - & $\begin{array}{l}2 \cdot 94 \\
47\end{array}$ & $\begin{array}{l}2 \cdot 78 \\
58\end{array}$ & $\begin{array}{l}2 \cdot 70 \\
62\end{array}$ & $\begin{array}{l}2 \cdot 52 \\
99\end{array}$ & $\begin{array}{l}2 \cdot 08 \\
30\end{array}$ & $\begin{array}{l}1.83 \\
45\end{array}$ & $\begin{array}{l}1 \cdot 70 \\
45\end{array}$ & $\begin{array}{l}1 \cdot 60 \\
34\end{array}$ & $\begin{array}{l}1.47 \\
35\end{array}$ & $\begin{array}{l}- \\
-\end{array}$ \\
\hline $\begin{array}{l}\gamma \text {-FeOOH } \\
\text { Hydrazinate/ } \\
\text { autocatalytic }\end{array}$ & $\begin{array}{l}D \\
I / I_{0}\end{array}$ & - & $\begin{array}{l}2 \cdot 96 \\
53\end{array}$ & & $\begin{array}{l}- \\
-\end{array}$ & $\begin{array}{l}2 \cdot 52 \\
100\end{array}$ & $\begin{array}{l}2 \cdot 09 \\
33\end{array}$ & $\begin{array}{l}- \\
-\end{array}$ & $\begin{array}{l}1 \cdot 70 \\
27\end{array}$ & $\begin{array}{l}1.61 \\
33\end{array}$ & $\begin{array}{l}1.48 \\
43\end{array}$ & $\begin{array}{l}1 \cdot 27 \\
17\end{array}$ \\
\hline $\begin{array}{l}\alpha-\mathrm{FeOOH} \\
\text { Hydrazinate/ } \\
\text { autocatalytic }\end{array}$ & $\begin{array}{l}D \\
I / I_{0}\end{array}$ & - & & $\begin{array}{l}- \\
-\end{array}$ & $\begin{array}{l}2 \cdot 70 \\
78\end{array}$ & $\begin{array}{l}2 \cdot 52 \\
100\end{array}$ & - & $\begin{array}{l}1 \cdot 83 \\
42\end{array}$ & $\begin{array}{l}1.69 \\
42\end{array}$ & $\begin{array}{l}1.60 \\
36\end{array}$ & $\begin{array}{l}1.48 \\
51\end{array}$ & $\begin{array}{l}1 \cdot 27 \\
23\end{array}$ \\
\hline $\begin{array}{l}\text { Amorphous } \mathrm{FeOOH} \\
\text { Hydrazinate/ } \\
\text { autocatalytic }\end{array}$ & $\begin{array}{l}D \\
I / I_{0}\end{array}$ & - & $\begin{array}{l}- \\
-\end{array}$ & - & - & $\begin{array}{l}2 \cdot 51 \\
99\end{array}$ & $\begin{array}{l}2 \cdot 08 \\
58\end{array}$ & $\begin{array}{l}- \\
-\end{array}$ & $\begin{array}{l}- \\
-\end{array}$ & $\begin{array}{l}1 \cdot 60 \\
74\end{array}$ & $\begin{array}{l}1.47 \\
81\end{array}$ & $\begin{array}{l}1 \cdot 27 \\
71\end{array}$ \\
\hline
\end{tabular}

*Reported values from JCPDS files Nos. 6-615; 13-534; 19-629; 24-81 and 25-1402. 


\subsection{Chemical formula fixation}

3.3a Iron oxyhydroxides: The total weight loss values, iron contents, density and IR band positions of the iron oxyhydroxides are shown in table 2 . From the analytical observations the following chemical formulas have been fixed for the oxyhydroxides

$\gamma$-FeOOH$\cdot 0 \cdot 3 \mathrm{H}_{2} \mathrm{O} ; \alpha-\mathrm{FeOOH} \cdot 0 \cdot 2 \mathrm{H}_{2} \mathrm{O}$ and amorphous $\mathrm{FeOOH} \cdot 0 \cdot 8 \mathrm{H}_{2} \mathrm{O}$.

At high temperatures $\left(\sim 250^{\circ} \mathrm{C}\right)$ the simple dehydration of $\alpha$-FeOOH yields $\alpha-\mathrm{Fe}_{2} \mathrm{O}_{3}$, while $\gamma$-FeOOH topotactically transforms (Dasgupta 1961) into $\gamma-\mathrm{Fe}_{2} \mathrm{O}_{3}$. An increase in temperature may lead to the phase transformation of $\gamma-\mathrm{Fe}_{2} \mathrm{O}_{3}$ to $\alpha-\mathrm{Fe}_{2} \mathrm{O}_{3}$.

3.3b Hydrazination of iron oxyhydroxides: The reddish orange $\gamma$-FeOOH$\cdot 0 \cdot 3 \mathrm{H}_{2} \mathrm{O}$ and reddish brown amorphous $\mathrm{FeOOH} \cdot 0 \cdot 8 \mathrm{H}_{2} \mathrm{O}$ when equilibrated with hydrazine in a hydrazine hydrate $(99 \%)$ atmosphere in a desiccator turned black, while yellow $\alpha$-FeOOH$\cdot 0 \cdot 2 \mathrm{H}_{2} \mathrm{O}$ did not change its colour. On exposure to air all fumed immediately into reddish brown magnetic oxide products. All hydrazinated compounds were unstable in an ordinary atmosphere and hence the hydrazine uptake could not be analyzed to fix plausible formula of the complexes.

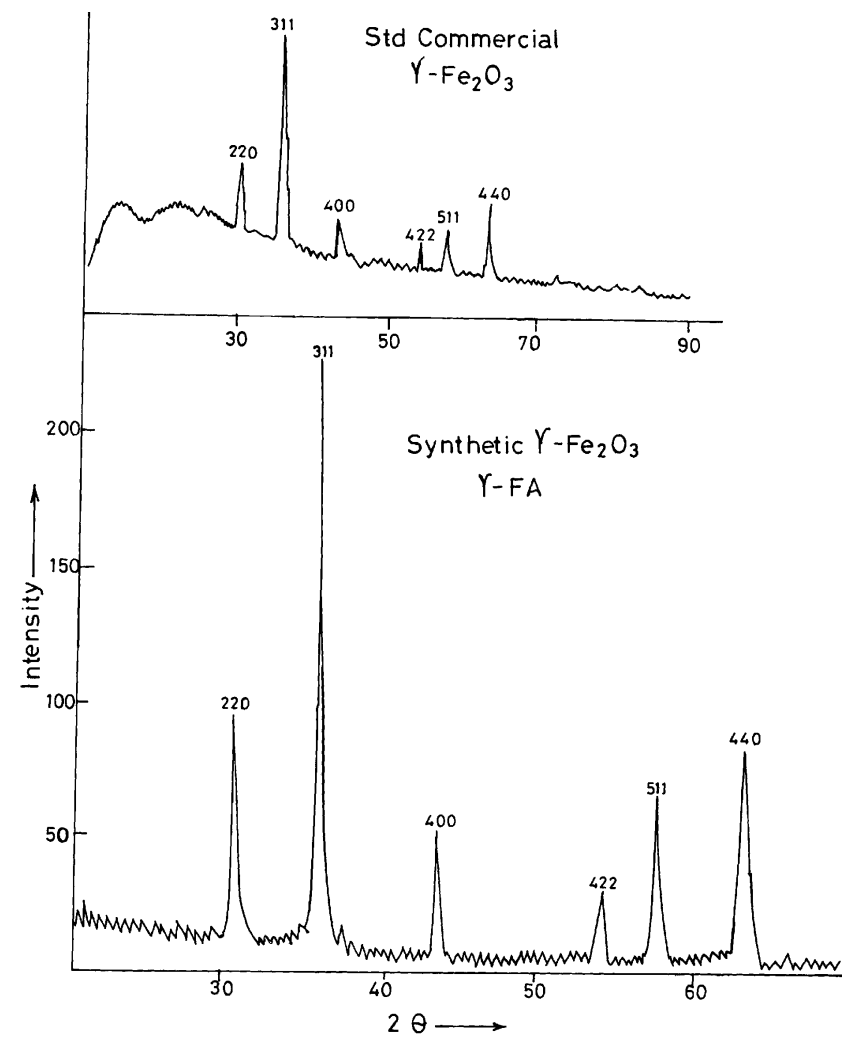

Figure 1. X-ray diffractogram of $\gamma-\mathrm{Fe}_{2} \mathrm{O}_{3}$.
Therefore, a special reactor was built to monitor the hydrazine uptake and analyse titrimetrically by $\mathrm{KIO}_{3}$.

\subsection{Equilibration with $80(\%) \mathrm{N}_{2} \mathrm{H}_{4} \cdot \mathrm{H}_{2} \mathrm{O}$}

In a special reactor when hydrazine uptake was analyzed the hydrazine contents of $10.4 \%$ and $10.8 \%$ were observed, respectively, in $\gamma$-FeOOH$\cdot 0 \cdot 3 \mathrm{H}_{2} \mathrm{O}$ and amorphous $\mathrm{FeOOH} \cdot 0 \cdot 8 \mathrm{H}_{2} \mathrm{O}$, while just $1.5 \%$ was found in $\alpha$-FeOOH$\cdot 0 \cdot 2 \mathrm{H}_{2} \mathrm{O}$. Both $\gamma$-FeOOH$\cdot 0 \cdot 3 \mathrm{H}_{2} \mathrm{O}$ and amorphous $\mathrm{FeOOH} \cdot 0 \cdot 8 \mathrm{H}_{2} \mathrm{O}$ turned black and the yellow colour of $\alpha-\mathrm{FeOOH} \cdot 0 \cdot 2 \mathrm{H}_{2} \mathrm{O}$ remained unchanged. On estimating the iron contents of the black coloured samples, it was observed that $\sim 41 \% \mathrm{FeO}$ was present in the product of hydrazinated $\gamma$-FeOOH$\cdot 0 \cdot 3 \mathrm{H}_{2} \mathrm{O}$, while amorphous $\mathrm{FeOOH}$ showed just $1.2 \% \mathrm{FeO}$. As the black coloured product of $\gamma$-FeOOH$\cdot 0 \cdot 3 \mathrm{H}_{2} \mathrm{O}$ contains $\sim 41 \% \mathrm{FeO}$, it must be ferrousoferric oxide of $\mathrm{Fe}_{3} \mathrm{O}_{4}=\mathrm{FeO} \cdot \mathrm{Fe}_{2} \mathrm{O}_{3}$ type whose theoretical $\mathrm{FeO}$ content is $31.03 \%$. These observations suggest that the black coloured product in $99 \%$ hydrazine hydrate equilibration was a ferrouso-ferric type oxide which may be the intermediate phase of the final fumed product $\gamma-\mathrm{Fe}_{2} \mathrm{O}_{3}$.

\subsection{Mechanism of hydrazine method of synthesis of metal oxides}

Hydrazine is a reducing agent and the $\mathrm{X}$-ray diffraction done (Tikkanen 1961) on the catalyst, $\alpha-\mathrm{Fe}_{2} \mathrm{O}_{3}$, on hydrazine decomposition found the oxide converted into $\mathrm{Fe}_{3} \mathrm{O}_{4}$. Hydrazine sulfate decomposition in an alkaline medium on $\alpha-\mathrm{Fe}_{2} \mathrm{O}_{3}$ also converts the oxide into magnetite (Fakuda 1957) and here the hydrazine sulfate first dissociates into hydrazine,

$$
\begin{aligned}
\left(\mathrm{N}_{2} \mathrm{H}_{4}\right)_{2} \cdot \mathrm{H}_{2} \mathrm{SO}_{4} \Rightarrow & \mathrm{N}_{2} \mathrm{H}_{5}^{1+}+\mathrm{SO}_{4}^{2-} \Rightarrow 2 \mathrm{~N}_{2} \mathrm{H}_{4} \\
& +2 \mathrm{H}^{1+}+\mathrm{SO}_{4}^{2-} .
\end{aligned}
$$

The reduction of $\mathrm{Fe}_{2} \mathrm{O}_{3}$ is then a coupled reaction,

$$
\begin{aligned}
& \mathrm{N}_{2} \mathrm{H}_{5}^{1+} \Rightarrow \mathrm{N}_{2}+5 \mathrm{H}^{1+}+4 e^{-} \\
& 3 \mathrm{Fe}_{2} \mathrm{O}_{3}+2 \mathrm{H}^{1+}+2 e^{-} \Rightarrow 2 \mathrm{Fe}_{3} \mathrm{O}_{4}+\mathrm{H}_{2} \mathrm{O}
\end{aligned}
$$

Similarly a hydrous ferric oxide decomposes hydrazine sulfate (Furuichi et al 1969) and transforms itself into magnetite

$$
3 \mathrm{Fe}_{2} \mathrm{O}_{3-x / 2}(\mathrm{OH})_{x}+2 \mathrm{H}^{1+}+2 e^{-} \Rightarrow 2 \mathrm{Fe}_{3} \mathrm{O}_{4}+(1+3 / 2 x) \mathrm{H}_{2} \mathrm{O}
$$

In the present study the formed magnetite type phase in the hydrazinated $\gamma$-FeOOH$\cdot 0 \cdot 3 \mathrm{H}_{2} \mathrm{O}$ transforms in air into maghemite, $\gamma-\mathrm{Fe}_{2} \mathrm{O}_{3}$. The hydrazinated amorphous $\mathrm{FeOOH}$, however, also shows black product consisting of $1.2 \%$ $\mathrm{FeO}$ which transforms into maghemite. The low per cent 


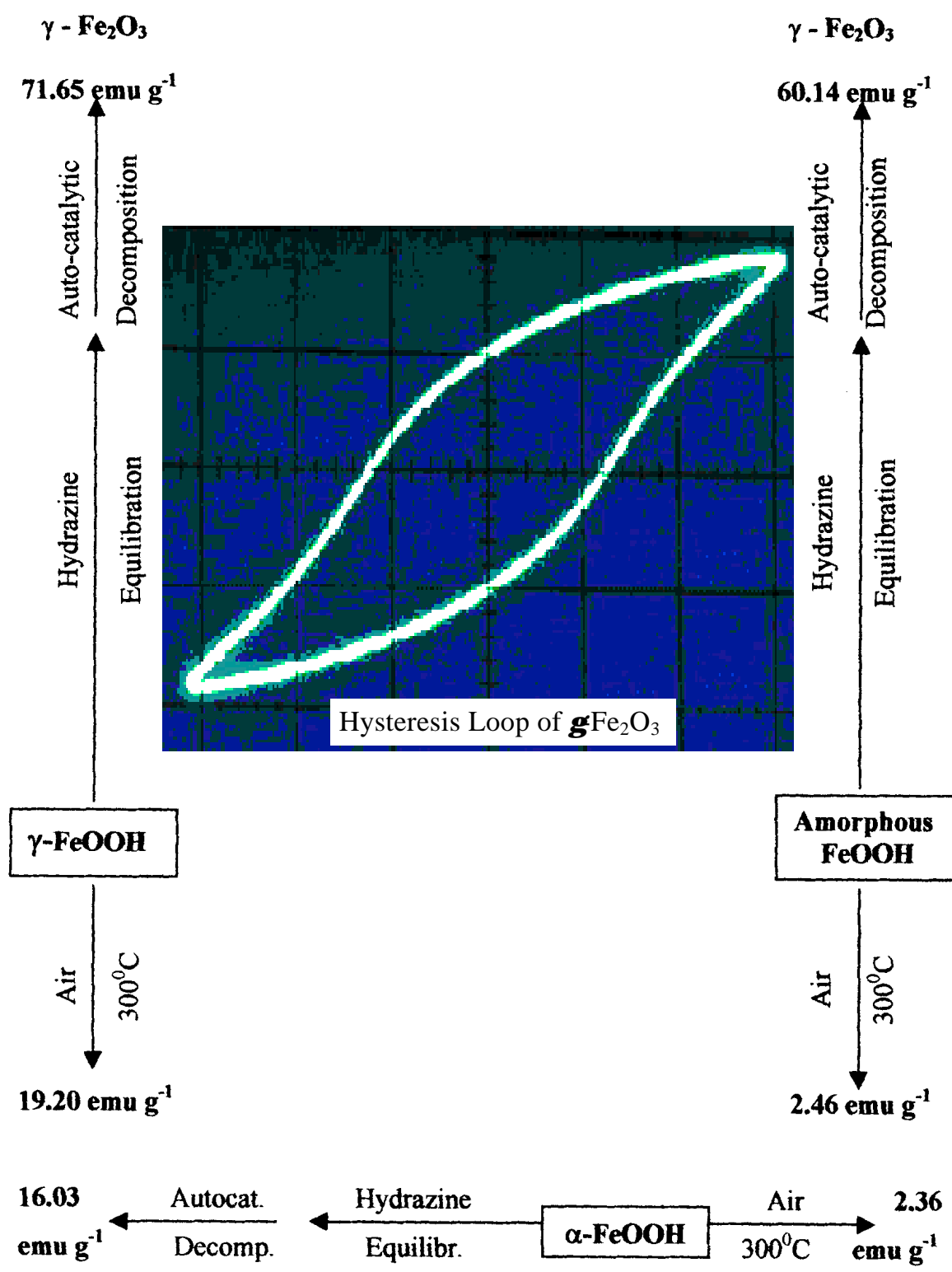

Figure 2. Saturation magnetization, $J_{\mathrm{s}}$, $\left(\mathrm{emu} \mathrm{g}^{-1}\right)$, values of the thermal products of the iron oxyhydroxides and hydrazinated iron oxyhydroxides. (Inset: A typical hysteresis loop of synthetic $\gamma-\mathrm{Fe}_{2} \mathrm{O}_{3}$ ).

Table 2. Chemical analysis, density, IR, total weight loss of iron oxyhydroxides.

\begin{tabular}{|c|c|c|c|c|c|c|c|}
\hline \multirow[b]{2}{*}{ Sample } & \multirow[b]{2}{*}{$\begin{array}{c}\% \mathrm{Fe} \\
\text { Obsd. (Calcd.) }\end{array}$} & \multirow[b]{2}{*}{$\begin{array}{l}\text { Density } \\
\left(\mathrm{g} \mathrm{cm}^{-1}\right)\end{array}$} & \multicolumn{3}{|c|}{$\begin{array}{l}\text { Infrared bands } \\
\qquad\left(\mathrm{cm}^{-1}\right)\end{array}$} & \multicolumn{2}{|c|}{$\begin{array}{c}\text { Total \% weight loss } \\
\text { Obsd. (Calcd.) }\end{array}$} \\
\hline & & & $\begin{array}{l}\mathrm{O}-\mathrm{H} \\
\text { stretch }\end{array}$ & $\begin{array}{l}\mathrm{O}-\mathrm{H} \\
\text { stretch }\end{array}$ & $\begin{array}{l}\mathrm{Fe}-\mathrm{O} \\
\text { bend }\end{array}$ & Air & $\mathrm{N}_{2}$ \\
\hline$\gamma$-FeOOH$\cdot 0 \cdot 3 \mathrm{H}_{2} \mathrm{O}$ & $59 \cdot 00(59 \cdot 25)$ & $1 \cdot 54$ & 2890 & 1020 & 747 & $\begin{array}{r}15 \cdot 62 \\
\quad(15\end{array}$ & $\begin{array}{l}15 \cdot 00 \\
8)\end{array}$ \\
\hline $\begin{array}{l}\text { Amorphous } \\
\text { FeOOH} \cdot 0 \cdot 8 \mathrm{H}_{2} \mathrm{O}\end{array}$ & $54 \cdot 00(54 \cdot 09)$ & 1.73 & & & & $\begin{array}{r}22 \cdot 90 \\
(22\end{array}$ & $\begin{array}{l}23 \cdot 00 \\
6)\end{array}$ \\
\hline$\alpha-\mathrm{FeOOH} \cdot 0 \cdot 2 \mathrm{H}_{2} \mathrm{O}$ & $60 \cdot 00(60 \cdot 41)$ & $2 \cdot 66$ & 3100 & 904 & 774 & $\begin{array}{r}13 \cdot 76 \\
(13\end{array}$ & $\begin{array}{l}15 \cdot 00 \\
3)\end{array}$ \\
\hline
\end{tabular}




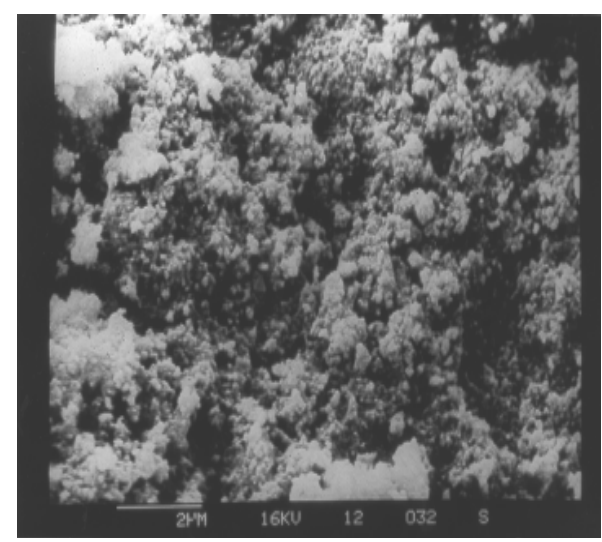

Synthetic $\gamma-\mathrm{Fe}_{2} \mathrm{O}_{3}$
$\longrightarrow \mathrm{MgFe}_{2} \mathrm{O}_{4}$
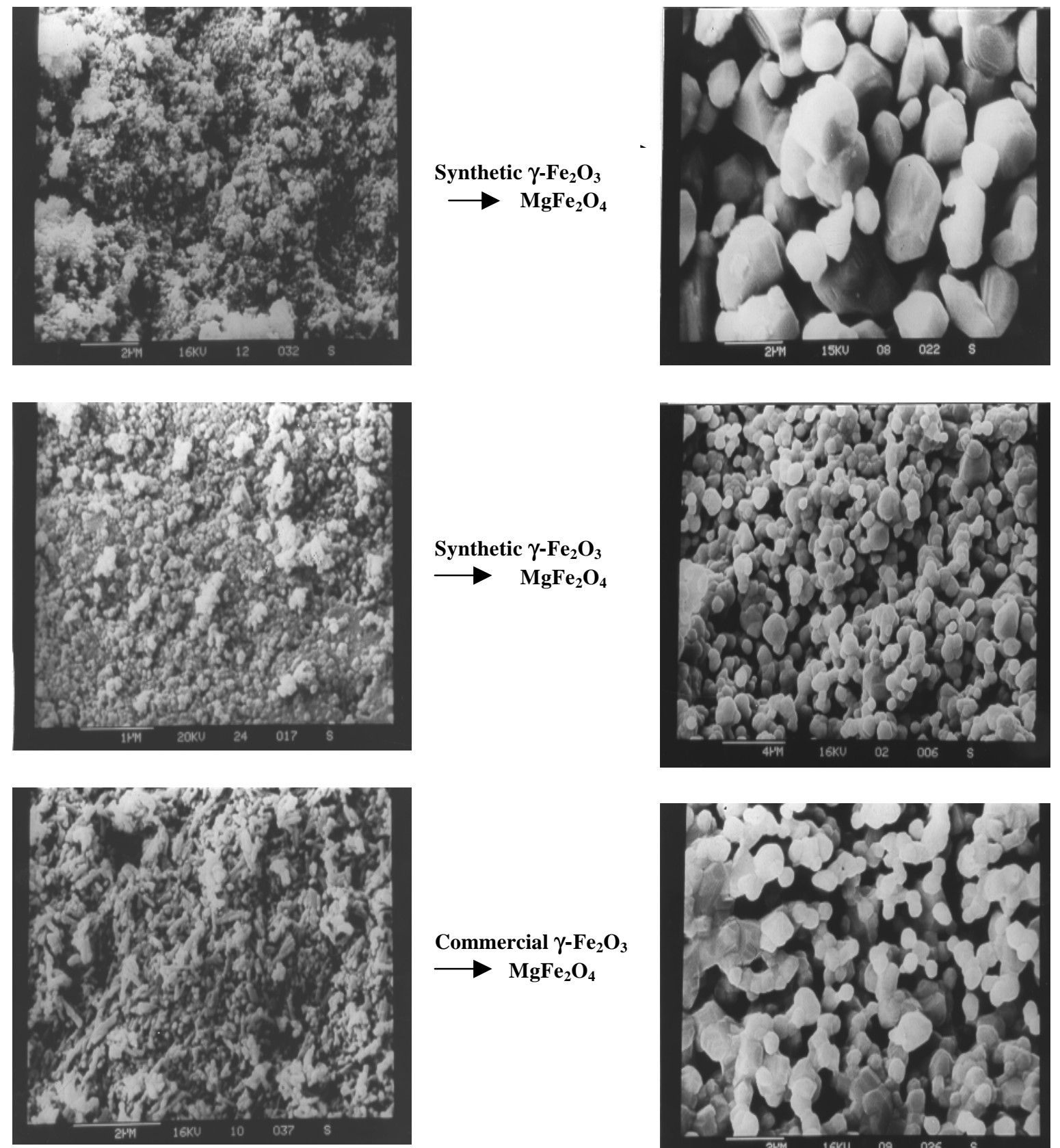

Commercial $\gamma-\mathrm{Fe}_{2} \mathrm{O}_{3}$

$\longrightarrow \mathrm{MgFe}_{2} \mathrm{O}_{4}$
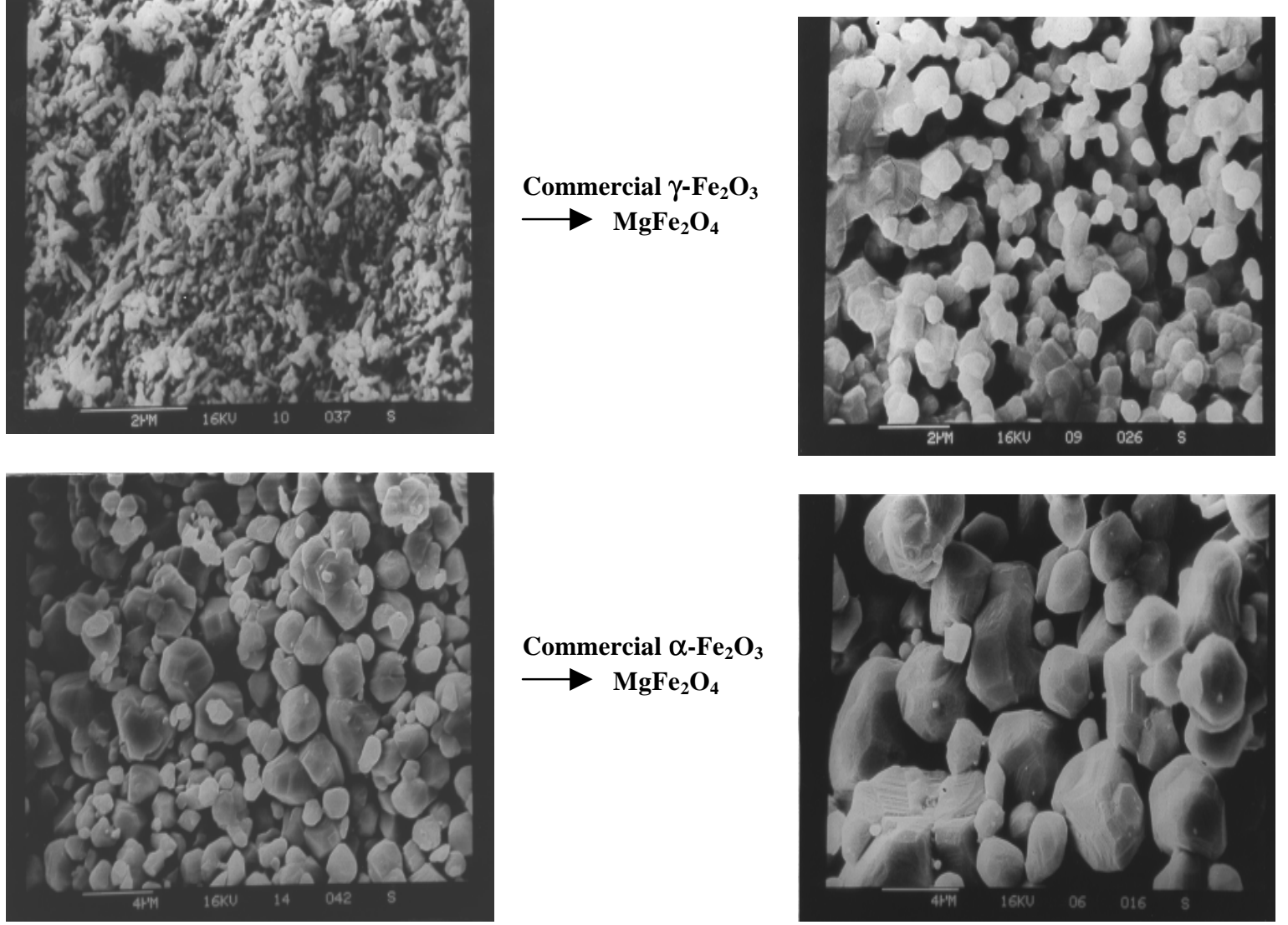

Commercial $\alpha-\mathrm{Fe}_{2} \mathrm{O}_{3}$ $\longrightarrow \mathrm{MgFe}_{2} \mathrm{O}_{4}$

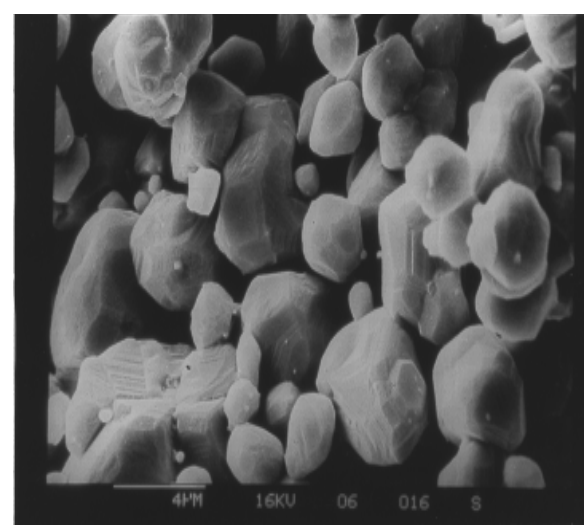

Figure 3. SEM micrographs of synthetic iron oxides and $\mathrm{MgFe}_{2} \mathrm{O}_{4}$. 
of $\mathrm{FeO}$ may be due to the formation of $\gamma-\mathrm{Fe}_{2} \mathrm{O}_{3}$ directly in the hydrazine atmosphere itself. The absence of $\mathrm{FeO}$ in the yellow product of the hydrazinated $\alpha-\mathrm{FeOOH}$ suggests that no intermediate magnetite phase is formed, but the product transforms into $\alpha-\mathrm{Fe}_{2} \mathrm{O}_{3}$. Hydrazination in $99 \%$ $\mathrm{N}_{2} \mathrm{H}_{4} \cdot \mathrm{H}_{2} \mathrm{O}$ makes the iron oxyhydroxides to fume immediately when exposed to air.

Hydrazine methods are adopted because the hydrazinated complexes, in general, especially carboxylato-hydrazinates, decompose explosively. Metal carboxylates are pyrophoric and the hydrazination further enhances their pyrophoric nature. And we observed (Rane et al 1981; Moye et al 1993) $\mathrm{FeC}_{2} \mathrm{O}_{4} \cdot 2 \mathrm{H}_{2} \mathrm{O}$ in air decomposes at $300-350^{\circ} \mathrm{C}$ to $\alpha-\mathrm{Fe}_{2} \mathrm{O}_{3}$, while in an inert atmosphere of $\mathrm{N}_{2}$ the decomposed product is black magnetic $\mathrm{Fe}_{3} \mathrm{O}_{4}$, but a controlled atmosphere of moisture at $\sim 310^{\circ} \mathrm{C}$ allows the formation of $\gamma-\mathrm{Fe}_{2} \mathrm{O}_{3}$. In fact, moist ferrous oxalate when heated in muffle furnace shows a bright glow at $\sim 310^{\circ} \mathrm{C}$ (Rao et al 1974), which on removal from the furnace and cooling the product indicates magnetic nature due to $\gamma$ $\mathrm{Fe}_{2} \mathrm{O}_{3}$. The $\mathrm{FeC}_{2} \mathrm{O}_{4} \cdot 2 \mathrm{H}_{2} \mathrm{O}$ on hydrazination (Moye et al 1993 ) forms $\mathrm{FeC}_{2} \mathrm{O}_{4} \cdot 2 \mathrm{~N}_{2} \mathrm{H}_{4}$ which when brought near a burning splinter catches fire and a glow that forms spreads through the bulk completing the decomposition autocatalytically to $\gamma-\mathrm{Fe}_{2} \mathrm{O}_{3}$. Thus, hydrazinated complexes are pyrophoric which allow the decomposition to take place easily at an ordinary temperature. Similar observations were also made on iron (II) carboxylato-hydrazinates such as ferrous fumarato-, succinato-, maleato-, malato-, malonato- and tartrato-hydrazinate (Verenkar 1997; Rane and Verenkar 2001) which autocatalytically decomposed to $\gamma-\mathrm{Fe}_{2} \mathrm{O}_{3}$. Iron oxyhydroxides also become pyrophoric on hydrazination.

The easy formation of $\gamma-\mathrm{Fe}_{2} \mathrm{O}_{3}$ from hydrazinated ferrous oxalate without controlling the moisture atmosphere, which otherwise is needed for the unhydrazinated complex, indicates that the required partial pressure of water is supplied by the decomposed products $\left(\mathrm{N}_{2}+\right.$ $\mathrm{H}_{2} \mathrm{O}$ ). Thus the hydrazine released from the hydrazinated ferrous oxalate reacts with the atmospheric oxygen liberating enormous energy (Schmidt 1984),

$$
\mathrm{N}_{2} \mathrm{H}_{4}+\mathrm{O}_{2} \rightarrow \mathrm{N}_{2}+\mathrm{H}_{2} \mathrm{O} ; \Delta \mathrm{H}=-621 \mathrm{~kJ} \mathrm{~mole}^{-1}
$$

which enables to oxidatively decompose the dehydrazinated complex to $\gamma-\mathrm{Fe}_{2} \mathrm{O}_{3}$. The decomposition of ferrous oxalate in air (Rane et al 1981, 1999) leads to,

$$
\begin{aligned}
\mathrm{FeC}_{2} \mathrm{O}_{4} \cdot 2 \mathrm{H}_{2} \mathrm{O} & \rightarrow \mathrm{FeC}_{2} \mathrm{O}_{4} \rightarrow\left(\mathrm{FeO} \rightarrow \mathrm{Fe}_{3} \mathrm{O}_{4}\right. \\
& \left.\rightarrow \gamma-\mathrm{Fe}_{2} \mathrm{O}_{3}\right) \Rightarrow \alpha-\mathrm{Fe}_{2} \mathrm{O}_{3}
\end{aligned}
$$

In inert atmosphere of $\mathrm{N}_{2}$ the decomposition arrests at $\mathrm{Fe}_{3} \mathrm{O}_{4}$, while the controlled atmosphere of moisture allows the magnetite to oxidize to $\gamma-\mathrm{Fe}_{2} \mathrm{O}_{3}$ without allowing it to go further to thermodynamically stable phase $\alpha-\mathrm{Fe}_{2} \mathrm{O}_{3}$. Thus, a metastable cubic spinel phase $\gamma-\mathrm{Fe}_{2} \mathrm{O}_{3}$ is the oxi- dation product of cubic inverse spinel $\mathrm{Fe}_{3} \mathrm{O}_{4}$ and the stabilization of the $\gamma-\mathrm{Fe}_{2} \mathrm{O}_{3}$ occurs in a controlled atmosphere of moisture. Therefore, the pyrophoric hydrazinated iron oxyhydroxide, $\gamma$-FeOOH, decomposes to $\mathrm{Fe}_{3} \mathrm{O}_{4}$ and further oxidation to metastable $\gamma-\mathrm{Fe}_{2} \mathrm{O}_{3}$ occurs under the moisture atmosphere, $\mathrm{N}_{2}+\mathrm{H}_{2} \mathrm{O}$ produced due to the oxidation of $\mathrm{N}_{2} \mathrm{H}_{4}$ in air.

All iron oxyhydroxides and iron hydroxides easily produce mainly $\gamma-\mathrm{Fe}_{2} \mathrm{O}_{3}$ or mixture of $\gamma-\mathrm{Fe}_{2} \mathrm{O}_{3}+\alpha-\mathrm{Fe}_{2} \mathrm{O}_{3}$ by hydrazine method. All show high BET surface area in the range $50-80 \mathrm{~m}^{2} \mathrm{~g}^{-1}$ and particles distribute in the $0-1 \mu$ size as revealed by SEM. The ferrite, $\mathrm{MgFe}_{2} \mathrm{O}_{4}$, prepared from these (Rane et al 1999, 2000) show superior magnetic and electrical properties as compared to the ferrite synthesized from commercial grade (1-2 $\mu$ sizes) $\alpha-\mathrm{Fe}_{2} \mathrm{O}_{3}$ and needle shape $\gamma-\mathrm{Fe}_{2} \mathrm{O}_{3}$. The SEM micrographs of some representative samples of the synthetic $\gamma-\mathrm{Fe}_{2} \mathrm{O}_{3}$ and the ferrite from these are reproduced in figure 3 (Sawant 1998; Rane et al 1999, 2000).

In fact, the commercial $\gamma-\mathrm{Fe}_{2} \mathrm{O}_{3}$ particles are acicular (needle shaped) suitable for use as a magnetic tape material. The $\mathrm{MgFe}_{2} \mathrm{O}_{4}$ prepared from such acicular shaped particle gave a dumb bell shaped porous ferrite (figure 3 ), while all synthetic submicron size non-acicular $\gamma-\mathrm{Fe}_{2} \mathrm{O}_{3}$ samples from the present studies gave well dense ferrites.

The commercial grade (1-2 $\mu$ sizes) $\alpha-\mathrm{Fe}_{2} \mathrm{O}_{3}$ ended up into porous ferrite. Uniform saturation magnetization values ( $4 \pi M_{\mathrm{s}} \cong 1000-1150$ Gauss) and Curie temperatures $\left(T_{\mathrm{c}}=670 \pm 30 \mathrm{~K}\right)$ and normal dielectric dispersions observed for low porosity (20-25\%) $\mathrm{MgFe}_{2} \mathrm{O}_{4}$ (Verenkar 1997; Sawant 1998; Rane et al 1999, 2001) suggest that iron oxides prepared from iron ore rejects are quite suitable for ferrite preparation. High porosity (40-41\%) mixed phase $\mathrm{MgFe}_{2} \mathrm{O}_{4}$ containing some unreacted $\alpha-\mathrm{Fe}_{2} \mathrm{O}_{3}$ obtained from commercial $\alpha-\mathrm{Fe}_{2} \mathrm{O}_{3}$ showed low $4 \pi M_{\mathrm{s}}$ value of $609 \mathrm{G}$. Thus, iron ore rejects can be efficiently chemically beneficiated to obtain value added iron oxide of ferrite grade.

\section{Acknowledgements}

One of the authors (KSR) thanks German Academic Exchange Service (DAAD), Deutsche Gesellschaft fur Technische Zusammenarbeit (GTZ) GmbH, International Seminar of University of Karlsruhe and Prof. W Weisweiler, Institute fur Chemische Technik of Univ. Karlsruhe, Germany, for financial support (in part) by way of Minor Research Equipment Grant. Also thanks are due to the Department of Science, Technology and Environment, Goa Government, for financial support in part.

\section{References}

Braibanti F, Dalavalle F, Pelinghelli M A and Leporati E 1968 Inorg. Chem. 71430 
Coey J M and Khalafalla D 1972 Phys. Status Solidi 11 229

Dasgupta D R 1961 Indian J. Phys. 35401

Fakuda M 1957 Nat. Tech. Rep. 31

Ferrari A, Braibanti A, Bigliardi G and Menotti Lanfredi A M 1966 Nature 2111174

Furuichi R, Sato N and Okamoto G 1969 Separatum of Chimia 23455

Huhn H J 1987 Z. Chem. 27334

Khalafalla D and Morrish A H 1972 J. Appl. Phys. 42624

Kikkawa T, Yoshinaka M, Hirota K and Yamaguchi O $1995 \mathrm{~J}$. Mater. Sci. Lett. 141071

Likhite S D, Radhakrishnamurthy C and Sahasrabudhe P W 1965 Rev. Sci. Instrum. 25302

Moye V, Rane K S and Kamat Dalal V N 1990 J. Mater. Sci. Mater. Electr. 1212

Moye V, Rane K S and Kamat Dalal V N 1993 J. Mater. Sci. Mater. Electr. 4241

Patil K C and Pai Verenker V R 1982 Mater. Res. Bull. 1729

Patil K C, Aruna S T and Ekambaram S 1997 Current opinion in solid state and material science 2158

Rane K S and Verenkar V M S 2001 Bull. Mater. Sci. 2439

Rane K S, Nikumbh A K and Mukhedkar A J 1981 J. Mater. Sci. 162387

Rane K S, Verenkar V M S and Sawant P Y 1999 J. Mater. Sci. Mater. Electr. 10 121, 133

Rane K S, Verenkar V M S and Sawant P Y 2000 Digest of the 8th international conference on ferrites (ICF 8), Kyoto, Japan, (Tokyo: The Japan Society of Powder and Powder Metallurgy), Paper No.19 PpI-2 page 158 (The complete paper will appear in the proceedings of the ICF (in press))
Rane K S, Verenkar V M S and Sawant P Y 2001 Bull. Mater. Sci. 24323

Rao C N R and Gopalakrishnan J 1997 New directions in solid state chemistry (New York: Cambridge University Press)

Rao V, Shashimohan A L and Biswas A B 1974 J. Mater. Sci. 9 430

Ravindranathan P and Patil Kashinath C 1987 Am. Ceram. Soc. Bull. 66688

Ruthner M J 1989 Proceedings of V international conference on ferrites, Bombay, (eds) C M Srivastava and M J Patni (New Delhi, Bombay, Calcutta: Oxford \& IBH Publishing Co. Pvt. Ltd.)

Ruthner M J 1997 J. Phys. IV (Paris) [Suppl. III] 53

Sano T and Tamaura Y 1999 Mater. Res. Bull. 34389

Sawant P Y 1998 Physico-chemical methods to determine the trace rare elements in Goan ore rejects and beneficiate the ore to get pure iron oxides useful for high-tech ferrite manufacture, Ph.D Thesis, Goa University, Goa

Schmidt E W 1984 Hydrazine and its derivatives (New York: John Wiley \& Sons Inc.)

Sharov V A, Bezdenezhnykh G V, Nikoneko E A and Krylov E I 1977 Russ. J. Inorg. Chem. 22356

Shrotri J J, Bagul A G, Kulkarni S D, Deshpande C E and Date S K 1992 Proceedings of the VI international conference on ferrites (Tokyo/Kyoto: The Japan Society of Powder and Powder Metallurgy) p. 404

Sugimoto M 1999 J. Am. Ceram. Soc. 82269

Tikkanen M H 1961 Werkstoffe U. Kossos 13480

Verenkar V M S 1997 Beneficiation of Goan ore rejects to get pure iron oxide and utilization of the iron oxide to synthesize ferrites, high-tech magnetic materials, Ph.D. Thesis, Goa University, Goa 